\title{
Impacts of bacteria and corrosion on removal of natural organic matter and disinfection byproducts in different drinking water distribution systems
}

\author{
Haibo Wang ${ }^{\text {a }}$, Ying Zhu ${ }^{\text {a, b }}$, Chun $\mathrm{Hu}^{\text {a, b, * }}$ \\ ${ }^{a}$ Key Laboratory of Drinking Water Science and Technology, Research Center for Eco-Environmental Sciences, Chinese Academy of Sciences, Beijing, 100085, \\ China \\ b University of Chinese Academy of Sciences, Beijing, 100049, China
}

\section{A R T I C L E I N F O}

\section{Article history:}

Received 22 July 2016

Received in revised form

7 November 2016

Accepted 21 November 2016

Available online 29 November 2016

\section{Keywords:}

Bacteria

Corrosion

Natural organic matter

UV disinfection

Disinfection byproducts

Drinking water distribution systems

\begin{abstract}
A B S T R A C T
Impacts of bacteria and corrosion on removal of natural organic matter (NOM) and disinfection byproducts (DBPs) were studied in simulated drinking water distribution systems (DWDSs) using two annular reactors (ARs) with different disinfection. The results verified that the removal of NOM and DBPs was related very well to the corrosion and bacterial regrowth in both ARs. The initial stages (before 50 days) at which the rate of corrosion is higher in both ARs is considered as stage I. At stage I, UV controlled bacterial regrowth and more chlorine reacted with iron to promote corrosion rate, inducing the higher removal of NOM and DBPs in AR treated with $\mathrm{UV} / \mathrm{Cl}_{2}$ than that treated with $\mathrm{Cl}_{2}$ alone. At stage II (from 50 days to 250 days), comparing with $\mathrm{Cl}_{2}$ disinfection alone, $\mathrm{UV} / \mathrm{Cl}_{2}$ decreased the number of the total bacteria in effluents and the dehalogenation related bacteria in biofilms effectively. Moreover, $\mathrm{UV} / \mathrm{Cl}_{2}$ induced the bacterial genus Dechloromonas dominant in the biofilms, resulting in the lower corrosion rate. The lower bacterial regrowth and corrosion rate caused the less removal of NOM and DBPs. These results are very helpful for the control of NOM and DBPs in DWDSs with different disinfection.
\end{abstract}

() 2016 Elsevier Ltd. All rights reserved.

\section{Introduction}

Chlorine has been used in the disinfection of drinking water for more than 100 years (Abdullah et al., 2009). However, during chlorine disinfection process, chlorine can react with natural organic matters (NOM) to form disinfection byproducts (DBPs), including trihalomethanes (THMs) and haloacetic acids (HAAs) (Lyon et al., 2014).

After disinfection, the remaining bacteria in drinking water may result in biofilms formation on the surface of pipes when the water goes through the drinking water distribution systems (DWDSs) (Usher et al., 2014). Therefore, a constant disinfectant residual concentration is needed to control the bacterial regrowth and biofilms formation in DWDSs (Hwang et al., 2012). Moreover, because the $\mathrm{UV} / \mathrm{Cl}_{2}$ disinfection can effectively inactivate the microorganisms and UV can decrease the initial $\mathrm{Cl}_{2}$ concentration which would minimize DBPs formation, $\mathrm{UV} / \mathrm{Cl}_{2}$ disinfection is

\footnotetext{
* Corresponding author

E-mail address: huchun@rcees.ac.cn (C. Hu).
}

always used in the water disinfection (Shah et al., 2011).

UV irradiation might change NOM structure and split large NOM molecules into organic acids with lower molecular weight (Choi and Choi, 2010). The changes of NOM structure resulting from the UV application might affect subsequent DBPs formation when the sequential $\mathrm{Cl}_{2}$ disinfection was used. Liu et al. (2006, 2012) have found that UV irradiation changed NOM structure and increased chloroform, dichloroacetic acid and trichloroacetic acid formation from subsequent chlorine disinfection. However, Liu et al. (2002) and Dotson et al. (2010) have reported little effect on THMs and HAAs formation when UV was applied at 40-186 mJ/ $\mathrm{cm}^{2}$ doses.

Moreover, iron pipes are still being used in DWDSs in many countries now, and the iron pipes are usually subject to corrosion (Sarin et al., 2001; Zarasvand and Rai, 2014). The main iron corrosion products were goethite $(\alpha-\mathrm{FeOOH})$, magnetite $\left(\mathrm{Fe}_{3} \mathrm{O}_{4}\right)$, lepidocrocite $(\beta-\mathrm{FeOOH})$ and green rust (Chun et al., 2005). Many studies have reported the adsorption of $\mathrm{NOM}$ by $\mathrm{Fe}^{0}$ and its corrosion products (Tsang et al., 2009; Rao et al., 2009). Some studies have also demonstrated that a variety of chlorinated and brominated DBPs are susceptible to reduction by many iron oxides such as $\mathrm{Fe}^{\mathrm{II}} /$ goethite, $\mathrm{Fe}^{\mathrm{II}} /$ magnetite and carbonate green rust (Chun 
et al., 2007; Lee et al., 2008). In addition, many halogenated DBPs can be reduced by zero-valent iron $\left(\mathrm{Fe}^{0}\right)$ (Hozalski et al., 2001; Lee et al., 2007). Moreover, pipe corrosion can also protect microorganisms in biofilms from disinfection, and some bacteria including Afipia and Methylobacterium in biofilms can reduce some DBPs (Zhang et al., 2009). Therefore, $\mathrm{Fe}^{0}$, corrosion products and the biofilms in the cast iron pipes may play great roles on the changes of NOM and DBPs in DWDSs.

Although some studies have evaluated the spatial and temporal variability of DBPs in small and real DWDSs (Shanks et al., 2013; Guilherme and Rodriguez, 2015), there is little known about the reason for removal of NOM and DBPs in DWDSs with different disinfection. Therefore, impacts of bacteria and corrosion on the removal of NOM and DBPs in DWDSs with $\mathrm{Cl}_{2}$ disinfection alone and $\mathrm{UV} / \mathrm{Cl}_{2}$ disinfection were studied in this paper. The relationship among NOM and DBPs removal, corrosion process and bacterial regrowth in DWDSs was also discussed.

\section{Materials and methods}

\subsection{The simulated drinking water distribution systems}

The simulated DWDSs were set up using two annular reactors (ARs) (Model 1320LJ, BioSurface Technologies Co., USA). Twenty cast iron coupons were housed in the rotating inner drum of the AR. The exposed surface area of each cast iron coupon was $17.5 \mathrm{~cm}^{2}$, and the main composition of the coupon was Fe (90.48\%, wt\%). Both ARs were run at a rotational speed of $50 \mathrm{rpm}$, and the hydraulic retention time for both ARs was $6 \mathrm{~h}$, which was determined by the flow rate of $2.5 \mathrm{~mL} / \mathrm{min}$.

Two ARs were run in parallel for 250 days. The water as influents in one AR was treated with chlorine disinfection alone, and the other one was treated with $\mathrm{UV} / \mathrm{Cl}_{2}$ disinfection. The fluence of the UV lamp was determined by ultraviolet irradiation meter (Handy, Beijing, China), and a fluence of $40 \mathrm{~mJ} / \mathrm{cm}^{2}$ was used in this study. The solution of sodium hypochlorite $(\mathrm{NaClO})$ was used as the chlorine disinfectant. Because free chlorine could react with ammonia nitrogen in the water to form chloramines, total chlorine concentration was measured using HANNA HI93711 spectrophotometer (Italy). In order to control different total chlorine concentration in the effluents of both ARs, different concentration of chlorine disinfectant was prepared and added into the disinfection tank, and then the total chlorine concentration in the influents and effluents of both ARs was measured. Before 50 days, the corrosion in both ARs was very fast because new cast iron coupons were used. This stage was stage I, and the initial total chlorine concentration in the influents of both ARs was about $0.85 \mathrm{mg} / \mathrm{L}$. After 50 days, the relatively stable corrosion scales were formed on the surface of cast iron coupons in both ARs, and ARs were run into stage II. At stage II, the initial total chlorine concentration in the influents of both ARs were different, however, both of the total chlorine concentration in effluents of two ARs was controlled at $0.08 \mathrm{mg} / \mathrm{L}$. This stage continued for 200 days.

\subsection{NOM and DBPs analysis}

The tested water was collected from a drinking water treatment plant in Beijing city of China. The water was treated by coagulationsettlement, sand filtration, and ozonization-biological activated carbon. The tested water had a $\mathrm{pH} 7.16-7.77$, turbidity $0.08-0.25$ NTU, alkalinity 104-150 mg CaCO $3 / \mathrm{L}$, DOC $1.78-2.19 \mathrm{mg} / \mathrm{L}, \mathrm{Cl}^{-}$ $19.8-32.7 \mathrm{mg} / \mathrm{L}, \mathrm{NO}_{3}^{-} 6.21-10.4 \mathrm{mg} / \mathrm{L}$ and $\mathrm{SO}_{4}^{2-} 50.4-103 \mathrm{mg} / \mathrm{L}$. The water was disinfected and pumped into both ARs in laboratory. The effluents of both ARs were taken weekly, and NOM and DBPs were analyzed.
A total organic carbon analyzer (TOC-V CPH, Shimadzu, Japan) was used to detect the dissolved organic carbon (DOC) concentration. High performance size exclusion chromatography (HPSEC) was used to measure the molecular size distribution of NOM. Weight-averaged molecular weight $(\mathrm{Mw})$ was calculated according to the methods of Her et al. (2002). Fourier transform infrared (FTIR) spectroscopy (Thermo Nicolet NEXUS 670) was used to analyze the structure of NOM, and it was set to scan from 4000 to $400 \mathrm{~cm}^{-1}$

DBPs including THMs and HAAs were detected by a gas chromatograph equipped with an electron capture detector (GC-ECD, $6890 \mathrm{~N}$; Agilent). THMs were measured using the following temperature program: hold at $35^{\circ} \mathrm{C}$ for $4 \mathrm{~min}$ and ramp to $65^{\circ} \mathrm{C}$ at $2{ }^{\circ} \mathrm{C} /$ min. HAAs were measured using the following temperature program: hold at $35^{\circ} \mathrm{C}$ for $4 \mathrm{~min}$, ramp to $260^{\circ} \mathrm{C}$ at $10^{\circ} \mathrm{C} / \mathrm{min}$ and hold for $4 \mathrm{~min}$.

Differences in water quality parameters between the two ARs were analyzed using analysis of variance (ANOVA) with a significance threshold of $\alpha=0.05$.

\subsection{Corrosion process and corrosion products characterization}

The corrosion rate of the cast iron coupons in different ARs was characterized by weight loss method according to our previous works (Wang et al., 2015). The scraped coupons were freeze-dried under vacuum conditions, and weighted to determine the weight loss.

Moreover, the corrosion behavior of the cast iron coupons were undertaken on coupons of the size $1 \times 1 \mathrm{~cm}$ embedded in a threeelectrode electrochemical cell. Working electrode potentials were referred to a saturated calomel electrode (SCE). The Tafel curves were recorded by scanning the potential $-1000 \mathrm{mV}$ and $0 \mathrm{mV}$ versus the open circuit potential (OCP) at a sweep rate of $2 \mathrm{mV} / \mathrm{s}$. The Electrochemical Workstation CHI 660 D (CH Instrument, China) was used to analyze the corrosion current densities $\left(i_{\text {corr }}\right)$.

The X-ray powder diffractometer (XRD, X'Pert PRO MPD; PANalytical, The Netherlands) was used to determine the chemical composition of the corrosion products on the surface of cast iron coupons in different ARs, using $\mathrm{Cu} K \alpha$ radiation $(\lambda=1.5406 \AA)$ at a scanning range of $2 \theta=10-70^{\circ}$.

Moreover, the total iron concentration and turbidity in effluents of both ARs were measured according to standard methods (EPA of China, 2002). The differences of the water quality parameters between the two ARs at different stages were also analyzed using analysis of variance (ANOVA) with a significance threshold of $\alpha=0.05$.

\subsection{Quantitative real time $P C R(q P C R)$ and 454 pyrosequencing}

A FastDNA spin kit for soil (Qbiogene, Solon, $\mathrm{OH}$ ) was used to extract the DNA of all samples. DNA quantity and quality were determined by a NanoDrop (ND-1000, NanoDrop, USA). The primer pairs 1369F (5'-CGGTGAATACGTTCYCGG-3') and 1492R (5'ACGGCTACCTTGTTACGACT-3') with the probe $1389 \mathrm{~F}$ ( $5^{\prime}$ - CTTGTACACACCGCCCGTC-3') were used to quantify the 16S rRNA of total bacteria (Suzuki et al., 2000). qPCR of all samples was performed in triplicate with the Applied Biosystems 7300 system, and the annealing temperature was $60{ }^{\circ} \mathrm{C}$. The $\mathrm{R}^{2}$ and amplification efficiency values for quantification were 0.992 and $96.5 \%$, respectively.

For 454 pyrosequencing, DNA was amplified by PCR with forward primer 341F (5'-CCTACGGGAGGCAGCAG-3') and reverse primer 1073R (5'-ACGAGCTGACGACARCCATG-3'). The PCR products were purified with AxyPrep DNA Gel Extraction Kit (Axygen, USA). Roche massively parallel 454 GS-FLX Titanium sequencer (Roche 454 Life Sciences, Branford, CT, USA) was used for the 
pyrosequencing. After sequencing, the sequences were processed according to our previous works (Wang et al., 2014), including PCR chimeras filtering, operational taxonomic unit (OTU) clustering and taxonomic classification.

\section{Results and discussion}

\subsection{Chlorine consumption}

Two ARs were used to simulate the DWDSs in this study. One was treated with $\mathrm{UV} / \mathrm{Cl}_{2}$ disinfection, and the other one was treated with chlorine disinfection alone. At stage I (before 50 days), the average total chlorine concentration in the influents of the AR treated with $\mathrm{UV} / \mathrm{Cl}_{2}$ was $0.84 \pm 0.04 \mathrm{mg} / \mathrm{L}$, and it was $0.85 \pm 0.03 \mathrm{mg} / \mathrm{L}$ in the AR treated with $\mathrm{Cl}_{2}$ alone. There was no significant difference of chlorine concentration in the influents $(\mathrm{p}=0.18>0.05)$ between the two ARs by ANOVA analysis. The total chlorine concentration was almost zero in effluents of the both ARs. The chlorine was completely consumed in both ARs (Fig. 1a). At stage II (from 50 to 250 days), in order to control the same total chlorine concentration $0.08 \mathrm{mg} / \mathrm{L}$ in effluents of both ARs, the average total chlorine concentration in the influents was $1.99 \pm 0.12 \mathrm{mg} / \mathrm{L}$ for the AR treated with $\mathrm{UV} / \mathrm{Cl}_{2}$, and $2.33 \pm 0.16 \mathrm{mg} /$ $\mathrm{L}$ for the AR treated with $\mathrm{Cl}_{2}$ alone. The chlorine consumption in both ARs was $1.91 \pm 0.12 \mathrm{mg} / \mathrm{L}$ and $2.26 \pm 0.13 \mathrm{mg} / \mathrm{L}$, respectively (Fig. 1a), and it was significantly different $(p<0.01)$ between the two ARs.

At stage I, because of the reaction between chlorine and iron in ARs due to the corrosion, the chlorine was completely consumed. At stage II, the corrosion products were formed and inhibited the corrosion. At this stage, chlorine consumption in ARs may be caused by corrosion, disinfection and the reaction with NOM. Therefore, the lower chlorine consumption suggested the reaction process which was caused by chlorine was slower in AR treated with $\mathrm{UV} / \mathrm{Cl}_{2}$.

\subsection{Changes of NOM}

\subsubsection{DOC concentration}

At stage I, DOC concentration in the influents of AR treated with $\mathrm{UV} / \mathrm{Cl}_{2}$ varied from $1.67 \mathrm{mg} / \mathrm{L}$ to $2.17 \mathrm{mg} / \mathrm{L}$, and it changed from $1.61 \mathrm{mg} / \mathrm{L}$ to $2.20 \mathrm{mg} / \mathrm{L}$ in the influents of AR treated with $\mathrm{Cl}_{2}$ alone. There was no difference between the DOC concentration in two influents $(\mathrm{p}=0.44>0.05)$. The DOC removal was $0.12-0.25 \mathrm{mg} / \mathrm{L}$ in the AR treated with $\mathrm{UV} / \mathrm{Cl}_{2}$, and it was $0.05-0.12 \mathrm{mg} / \mathrm{L}$ in the AR treated with chlorine alone (Fig. 1b). The average concentration of DOC removal was $0.20 \pm 0.05 \mathrm{mg} / \mathrm{L}$ and $0.08 \pm 0.03 \mathrm{mg} / \mathrm{L}$ for the both ARs, respectively, and it was significantly different between the two ARs $(\mathrm{p}<0.01)$.

At stage II, there was still no difference between the DOC concentration in two influents $(\mathrm{p}=0.82>0.05)$. However, the DOC removal was $0.03-0.24 \mathrm{mg} / \mathrm{L}$ in the AR treated with $\mathrm{UV} / \mathrm{Cl}_{2}$, and it was $0.10-0.28 \mathrm{mg} / \mathrm{L}$ in the AR treated with chlorine alone (Fig. 1b). The average concentration of DOC removal was $0.13 \pm 0.05 \mathrm{mg} / \mathrm{L}$ and $0.19 \pm 0.05 \mathrm{mg} / \mathrm{L}$ for both ARs, respectively, and it was also significantly different $(\mathrm{p}<0.01)$ between the both ARs.

The DOC removal was different in both ARs at the two stages. Comparing with $\mathrm{AR}$ treated with $\mathrm{Cl}_{2}$ alone, $\mathrm{UV} / \mathrm{Cl}_{2}$ disinfection


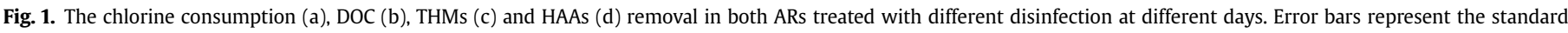
deviation from the average of three replications. 
increased the DOC removal at stage I, but decreased the DOC removal at stage II. DOC removal in DWDSs is mainly caused by reaction with chlorine, the sorption of corrosion products and bacterial regrowth (Codony et al., 2002; Rao et al., 2009; Lyon et al., 2014). At stage I, UV inactivated the bacteria in the influents of AR, therefore, more chlorine could react with iron to accelerate the corrosion, and this may be related with the more DOC removal in AR treated with $\mathrm{UV} / \mathrm{Cl}_{2}$. At stage II, the corrosion reached relative stable stage, UV could control the bacterial regrowth in the AR, and the chlorine consumption was also less in AR treated with $\mathrm{UV} / \mathrm{Cl}_{2}$. Therefore, DOC removal was lower in the AR treated with $\mathrm{UV} / \mathrm{Cl}_{2}$.

\subsubsection{Weight-averaged molecular weight (Mw) of NOM}

At stage I, $M w$ of NOM in the raw water was $615 \mathrm{Da}$, and it became 618 Da after UV disinfection (Table 1). Mw of NOM in the influents and effluents of the AR treated with $\mathrm{UV} / \mathrm{Cl}_{2}$ was $583 \mathrm{Da}$ and $581 \mathrm{Da}$, respectively. Mw of NOM in the influents and effluents of the AR treated with $\mathrm{Cl}_{2}$ alone was $574 \mathrm{Da}$ and $572 \mathrm{Da}$, respectively. At stage II, Mw of NOM in both ARs showed the same changes to those at stage I. This indicated that UV disinfection $\left(40 \mathrm{~mJ} / \mathrm{cm}^{2}\right)$ had little effect on the $M w$ of NOM, however, the chlorine could decrease the $M w$ of NOM in the influents of ARs because of the oxidation of NOM. Moreover, Mw of NOM took little changes when the water went through both ARs. Therefore, the chlorine may have reacted with NOM almost completely and the DBPs may also be mainly formed before the water went into the both ARs.

\subsubsection{FTIR spectra of NOM}

Because there was no difference of the FTIR spectra in the two stages, only the spectra of NOM at stage II were given (Fig. 2). All spectra show the similar features: (a) a peak at about $650 \mathrm{~cm}^{-1}$ assigned to $\mathrm{O}-\mathrm{C}=\mathrm{O}$ bending (Samios et al., 2007); (b) a peak at about $870 \mathrm{~cm}^{-1}$ assigned to $\mathrm{C}-\mathrm{H}$ vibration of aromatic ring (PerezSanz et al., 2006; Carvalho et al., 2008); (c) a peak at about $1140 \mathrm{~cm}^{-1}$ preferentially assigned to $\mathrm{C}-\mathrm{O}$ stretching (Kanokkantapong et al., 2006); (d) a peak at about $1420 \mathrm{~cm}^{-1}$ generally assigned to $\mathrm{O}-\mathrm{H}$ deformation and $\mathrm{C}-\mathrm{O}$ stretching in phenolic OH groups (Fernandez-Calvino et al., 2010); (e) a band at about $1610 \mathrm{~cm}^{-1}$ usually assigned to stretching of aromatic $\mathrm{C}=\mathrm{C}$, $\mathrm{C}=\mathrm{O}$ in amide groups, quinine $\mathrm{C}=\mathrm{O}$ and/or $\mathrm{C}=\mathrm{O}$ in $\mathrm{H}$-bonded conjugated ketones (Codony et al., 2002); (f) a strong, broad band at about $3400 \mathrm{~cm}^{-1}$ mainly due to $\mathrm{O}-\mathrm{H}$ stretching (Kanokkantapong et al., 2006; Fernandez-Calvino et al., 2010).

There was no change of the six peaks in raw water after UV disinfection, indicating that UV did not change the functional groups of NOM. However, during chlorine disinfection, two peaks at about $870 \mathrm{~cm}^{-1}$ and $1420 \mathrm{~cm}^{-1}$ were disappeared. The peaks at $1420 \mathrm{~cm}^{-1}$ and $870 \mathrm{~cm}^{-1}$ suggested a strong aromatic character, specifically associated with phenolates (Perez-Sanz et al., 2006). Therefore, the chlorine very easily reacted with the phenolic $\mathrm{OH}$ group and $\mathrm{C}-\mathrm{H}$ of aromatic ring, resulting in the DBPs formation. Moreover, the functional groups of NOM took little changes when the water went through the two ARs, suggesting little reaction between chlorine and NOM in ARs.

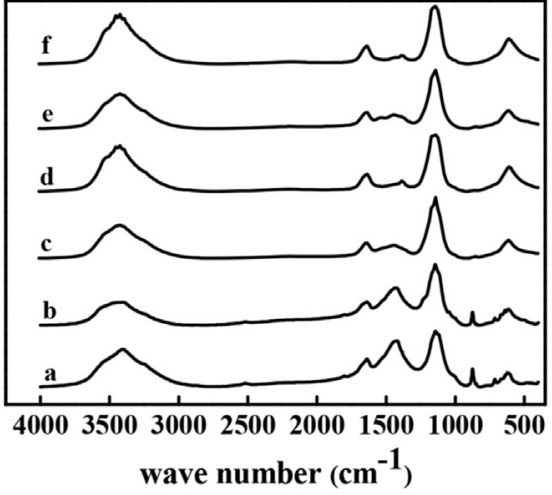

Fig. 2. Fourier transform infrared (FTIR) spectra of NOM in different waters (a - raw water, b - raw water after UV disinfection, c, d - influents and effluents of AR treated with $\mathrm{Cl}_{2}$ alone, e, $\mathrm{f}-$ influents and effluents of AR treated with $\mathrm{UV} / \mathrm{Cl}_{2}$ ).

\subsection{Removal of DBPs}

\subsubsection{Removal of THMs}

At stage $\mathrm{I}$, in the influents, $\mathrm{THM}_{\mathrm{s}}$ concentration varied from $13.6 \mu \mathrm{g} / \mathrm{L}$ to $19.3 \mu \mathrm{g} / \mathrm{L}$ in AR treated with $\mathrm{UV} / \mathrm{Cl}_{2}$, and it varied from $13.0 \mu \mathrm{g} / \mathrm{L}$ to $21.8 \mu \mathrm{g} / \mathrm{L}$ in AR treated with $\mathrm{Cl}_{2}$ alone. There was no difference between two ARs $(\mathrm{p}=0.87>0.05)$. When the water went through the both ARs respectively, the $\mathrm{THM}_{\mathrm{S}}$ removal was $2.26-9.53 \mu \mathrm{g} / \mathrm{L}$ in the AR treated with $\mathrm{UV} / \mathrm{Cl}_{2}$, and it was $1.02-7.59 \mu \mathrm{g} / \mathrm{L}$ in the AR treated with $\mathrm{Cl}_{2}$ alone (Fig. 1c). The average $\mathrm{THM}_{\mathrm{S}}$ removal was $6.05 \pm 1.13 \mu \mathrm{g} / \mathrm{L}$ and $4.30 \pm 1.20 \mu \mathrm{g} / \mathrm{L}$ for the both ARs, respectively, indicating that the average $\mathrm{THM}_{\mathrm{S}}$ removal in AR treated with $\mathrm{UV} / \mathrm{Cl}_{2}$ was more than that in AR treated with $\mathrm{Cl}_{2}$ alone at this stage.

At stage II, $\mathrm{THM}_{\mathrm{S}}$ concentration in the influents of both ARs was also the same $(\mathrm{p}=0.06>0.05)$. However, the $\mathrm{THM}_{\mathrm{s}}$ removal was $5.07-13.1 \mu \mathrm{g} / \mathrm{L}$ in the AR treated with $\mathrm{UV} / \mathrm{Cl}_{2}$, and it was $8.12-21.8 \mu \mathrm{g} / \mathrm{L}$ in the AR treated with $\mathrm{Cl}_{2}$ alone (Fig. 1c). The average removal of $\mathrm{THM}_{\mathrm{S}}$ was $10.2 \pm 0.83 \mu \mathrm{g} / \mathrm{L}$ and $14.9 \pm 1.07 \mu \mathrm{g} / \mathrm{L} \mathrm{mg} / \mathrm{L}$ for the both ARs, respectively. It was significantly different ( $\mathrm{p}=0.002<0.01)$ between the both ARs. At this stage, the $\mathrm{THM}_{\mathrm{S}}$ removal in AR treated with $\mathrm{UV} / \mathrm{Cl}_{2}$ was lower than that with $\mathrm{Cl}_{2}$ alone.

\subsubsection{Removal of $H A A s$}

At stage I, $\mathrm{HAA}_{\mathrm{s}}$ concentration varied from $10.4 \mu \mathrm{g} / \mathrm{L}$ to $17.2 \mu \mathrm{g} / \mathrm{L}$ in the influents of AR treated with $\mathrm{UV} / \mathrm{Cl}_{2}$, and it varied from $10.0 \mu \mathrm{g} / \mathrm{L}$ to $16.7 \mu \mathrm{g} / \mathrm{L}$ in the influents of AR treated with $\mathrm{Cl}_{2}$ alone. There was no difference between both ARs $(\mathrm{p}=0.44>0.05)$. The $\mathrm{HAA}_{\mathrm{s}}$ removal was $3.60-13.3 \mu \mathrm{g} / \mathrm{L}$ in the AR treated with $\mathrm{UV} / \mathrm{Cl}_{2}$, and it was $2.80-10.7 \mu \mathrm{g} / \mathrm{L}$ in the AR treated with $\mathrm{Cl}_{2}$ alone (Fig. $1 \mathrm{~d}$ ). The average $\mathrm{HAA}_{5}$ removal was $8.00 \pm 1.46 \mu \mathrm{g} / \mathrm{L}$ and $6.25 \pm 0.90 \mu \mathrm{g} /$ $\mathrm{L}$ for the both ARs, respectively. The average $\mathrm{HAA}_{\mathrm{s}}$ removal in AR treated with $\mathrm{UV} / \mathrm{Cl}_{2}$ was more than that in $\mathrm{AR}$ with $\mathrm{Cl}_{2}$ alone.

At stage II, $\mathrm{HAA}_{s}$ concentration in the influents of both ARs was also the same $(\mathrm{p}=0.32>0.05)$. The $\mathrm{HAA}_{\mathrm{s}}$ removal was 5.87-15.0 $\mu \mathrm{g} / \mathrm{L}$ in AR treated with $\mathrm{UV} / \mathrm{Cl}_{2}$, and it was $9.33-20.1 \mu \mathrm{g} / \mathrm{L}$

Table 1

Weight-averaged molecular weight (Mw) of NOM at different days in different ARs (Da).

\begin{tabular}{|c|c|c|c|c|c|c|}
\hline Samples & raw water & after UV & influent $1^{a}$ & effluent $1^{a}$ & influent $2^{\mathrm{b}}$ & effluent $2^{b}$ \\
\hline 50 days & 615 & 618 & 583 & 581 & 574 & 572 \\
\hline 230 days & 572 & 570 & 542 & 534 & 538 & 532 \\
\hline
\end{tabular}

${ }^{\text {a }}$ Influents and effluents of $\mathrm{AR}$ treated with $\mathrm{UV} / \mathrm{Cl}_{2}$ disinfection.

b Influents and effluents of AR treated with $\mathrm{Cl}_{2}$ disinfection. 
in AR treated with $\mathrm{Cl}_{2}$ alone (Fig. 1d). The average $\mathrm{HAA}_{s}$ removal was $9.44 \pm 0.91 \mu \mathrm{g} / \mathrm{L}$ and $13.8 \pm 0.83 \mu \mathrm{g} / \mathrm{L}$ for the both ARs, respectively. It was significantly different $(p=0.002<0.01)$ in both ARs. At this stage, the $\mathrm{HAA}_{\mathrm{S}}$ removal in the AR treated with $\mathrm{UV} / \mathrm{Cl}_{2}$ was lower than that treated with $\mathrm{Cl}_{2}$ alone.

The changes of HAAs in both ARs were similar with the changes of THMs. Moreover, the DBPs removal was consistent with the DOC consumption in both ARs at different stages. Therefore, the DBPs removal may be also caused by the corrosion and bacteria in ARs at different stages.

\subsection{The corrosion of cast iron coupons in both ARs}

In this study, the corrosion rate of the cast iron coupons was measured by average weight loss method. At stage I, the corrosion rate of the cast iron coupons was $0.287 \pm 0.015 \mathrm{~mm} / \mathrm{year}$ in AR treated with $\mathrm{UV} / \mathrm{Cl}_{2}$, and it was $0.195 \pm 0.003 \mathrm{~mm} /$ year in $\mathrm{AR}$ treated with $\mathrm{Cl}_{2}$ alone (Fig. 3a). However, at stage II, the corrosion rate of cast iron coupons in both ARs was $0.153 \pm 0.011 \mathrm{~mm} /$ year and $0.168 \pm 0.006 \mathrm{~mm} /$ year, respectively.

The polarization curves were measured for the corroded coupons in the two ARs. The Tafel analytical data of polarization curves are shown in Fig. 3b. In AR treated with $\mathrm{UV} / \mathrm{Cl}_{2}$, the corrosion current densities, $i_{\text {corr, }}$ of cast iron coupons decreased from $54.9 \mu \mathrm{A} \mathrm{cm}^{-2}$ at 50 days to $27.5 \mu \mathrm{A} \mathrm{cm} \mathrm{cm}^{-2}$ at 210 days. The results indicated that the corrosion rate of the cast iron coupons decreased
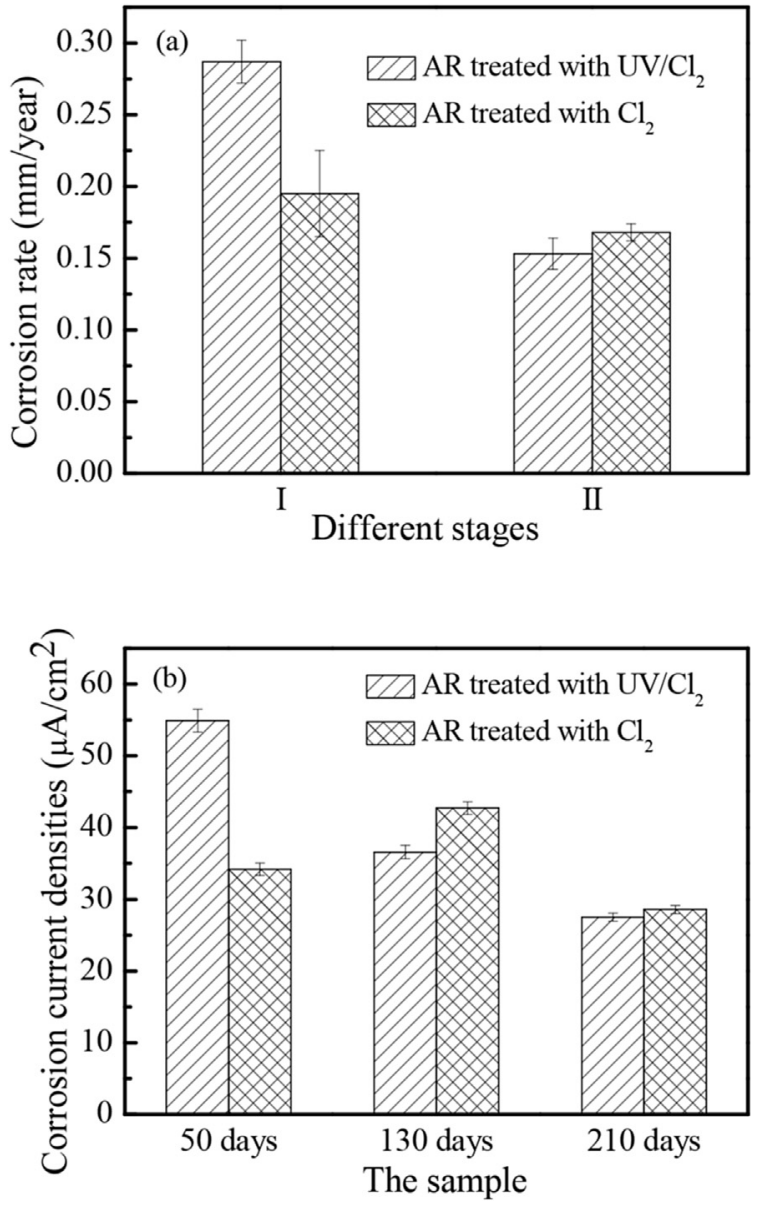

Fig. 3. The different corrosion rate of cast iron coupons in the two ARs measured (a) by weight loss method, and (b) by Tafel analysis of polarization curves. Error bars represent the standard deviation from the average of three replications. after 50 days. However, in AR treated with $\mathrm{Cl}_{2}$ alone, $i_{\text {corr }}$ increased from $34.2 \mu \mathrm{A} \mathrm{cm}^{-2}$ at 50 days to $42.7 \mu \mathrm{A} \mathrm{cm}^{-2}$ at 130 days, and then decreased to $28.6 \mu \mathrm{A} \mathrm{cm} \mathrm{cm}^{-2}$ at 210 days. This indicated that the corrosion rate of cast iron coupons increased and then decreased in this AR. The lower corrosion current densities in both ARs at stage II indicated the more corrosion products were formed to inhibit the corrosion.

The average turbidity at stage II $(0.27 \pm 0.06 \mathrm{NTU})$ was lower than that at stage I $(0.59 \pm 0.44 \mathrm{NTU})$ in the effluents of AR treated with $\mathrm{UV} / \mathrm{Cl}_{2}$ ( $\mathrm{p}=0.002$ ) (Fig. $4 \mathrm{a}$ ). The average turbidity in the effluents of AR treated with $\mathrm{Cl}_{2}$ alone also showed the same tendency (Fig. 4a). Moreover, the total iron concentration in effluents of both ARs showed the similar changes with turbidity (Fig. 4b). Li et al. (2014) also indicated that the total iron concentration and turbidity correlated very well in effluents of simulated DWDSs. The results suggested that the more corrosion products and dense corrosion layers were formed at stage II in both ARs to inhibit the corrosion and iron release, which also induced the turbidity lower in the effluents of both ARs at this stage.

Both the corrosion rate characterized by polarization curves and weight loss method indicated that the corrosion rate was higher in AR treated with $\mathrm{UV} / \mathrm{Cl}_{2}$ than that treated with $\mathrm{Cl}_{2}$ alone at stage I, meanwhile, the DOC and DBPs removal were also higher in the AR treated with $\mathrm{UV} / \mathrm{Cl}_{2}$ (Fig. 5). However, at stage II, the corrosion rate was higher in AR treated with $\mathrm{Cl}_{2}$ alone, and the DOC and DBPs removal were also higher in this AR (Fig. 5). Therefore, the corrosion rate may play great roles in the removal of DOC and DBPs in the simulated DWDSs. Comparing the two ARs, the higher corrosion
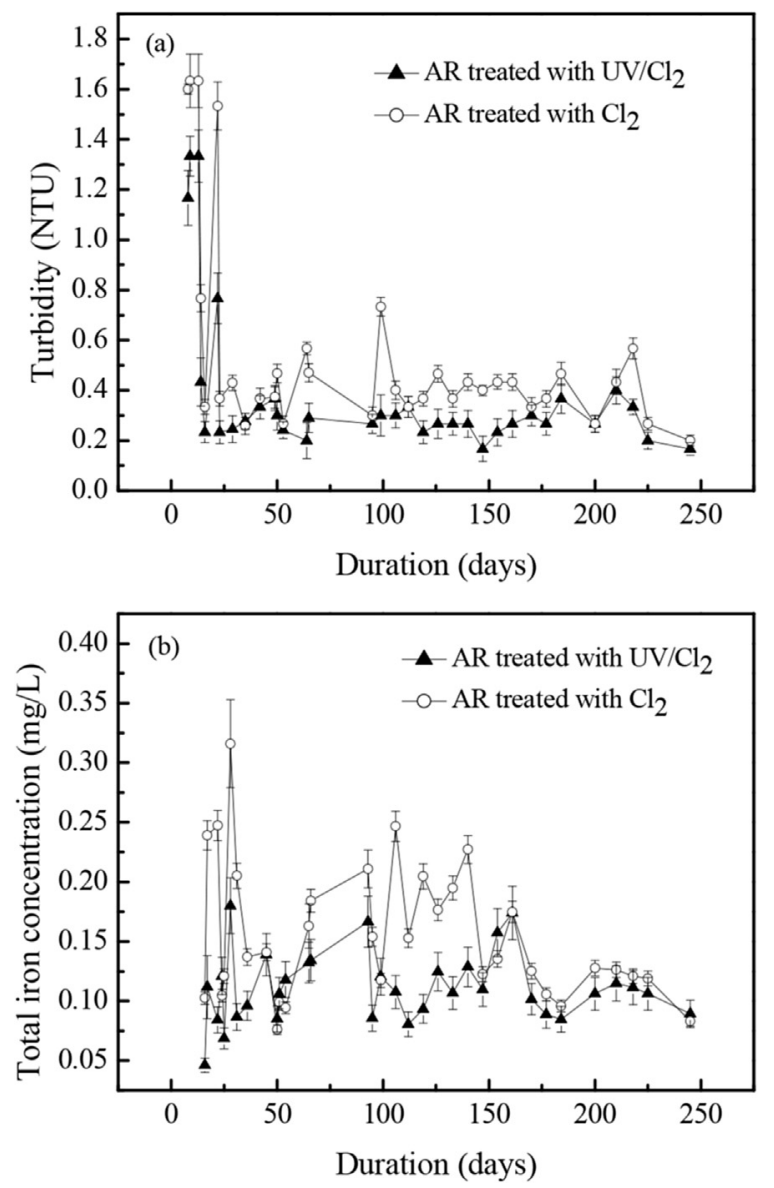

Fig. 4. The turbidity (a) and total iron concentration (b) in the effluents of both ARs treated with different disinfection. 


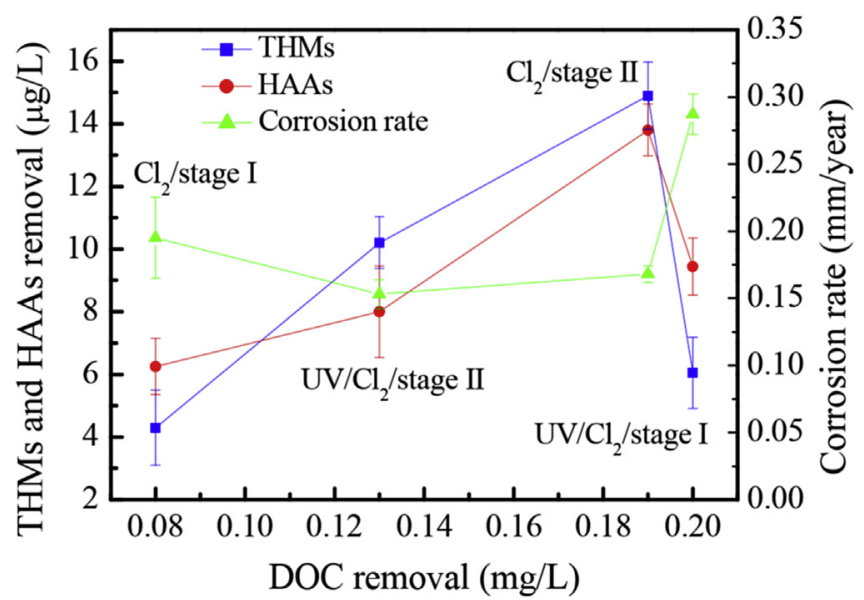

Fig. 5. The relationship among the removal of DOC, THMs, HAAs and corrosion rate in both ARs treated with different disinfection.

rate could induce higher removal of DOC and DBPs at different stages. However, although the corrosion rate was lower in both ARs at stage II than that at stage I, more DBPs removal was found in both ARs at stage II than at stage I (Fig. 5). This may be due to the more corrosion products formation in both ARs at stage II. More corrosion products could inhibit corrosion, but induced more DBPs removal by the reduction of DBPs (Chun et al., 2007; Lee et al., 2008).

At stage I, the corrosion because of the reaction between $\mathrm{Fe}^{0}$ and water including chlorine was the main chemical process in ARs. The higher corrosion current densities revealed this chemical process was much faster in AR treated with $\mathrm{UV} / \mathrm{Cl}_{2}$. This induced the formation of more corrosion products, such as green rust, goethite ( $\alpha$ $\mathrm{FeOOH})$, magnetite $\left(\mathrm{Fe}_{3} \mathrm{O}_{4}\right)$ and calcite $\left(\mathrm{CaCO}_{3}\right)$ (Fig. 6). Many studies have reported the sorption of NOM and reduction of DBPs by $\mathrm{Fe}^{0}$ and its corrosion products (Tsang et al., 2009; Rao et al., 2009; Xiao et al., 2014). Moreover, the DBPs could be reduced by the $\mathrm{Fe}^{0}$ (Hozalski et al., 2001; Lee et al., 2007), and some studies have also indicated that green rust and $\mathrm{Fe}_{3} \mathrm{O}_{4}$ could reduce the DBPs (Chun et al., 2007; Lee et al., 2008). Therefore, at stage I, more DOC and DBPs was removed in AR treated with $\mathrm{UV} / \mathrm{Cl}_{2}$. At stage II, the corrosion rate decreased in AR treated with $\mathrm{UV} / \mathrm{Cl}_{2}$, however, the corrosion rate increased from 50 days to 130 days and then decreased in AR treated with $\mathrm{Cl}_{2}$ alone. Therefore, the corrosion rate in AR treated with $\mathrm{Cl}_{2}$ alone was higher in this AR than that treated with $\mathrm{UV} / \mathrm{Cl}_{2}$, and the more removal of DOC and DBPs was detected in this AR at this stage. Moreover, more DBPs removal was found in



Fig. 6. X-ray diffraction (XRD) patterns of corrosion products on cast iron coupons at different stages in the AR treated with $\mathrm{UV} / \mathrm{Cl}_{2}$ and $\mathrm{Cl}_{2}$ only (GR - green rust, $\mathrm{G}-$ goethite, $\mathrm{Ca}$ - calcite, $\mathrm{M}$ - magnetite). both ARs at stage II than at stage I, which was due to the more corrosion products formation at this stage.

\subsection{S rRNA and bacterial communities in both ARs}

At stage I, the gene copy number of 16S rRNA in effluents and biofilms of AR treated with $\mathrm{UV} / \mathrm{Cl}_{2}$ was $3.46 \times 10^{10}$ gene copies/L and $1.75 \times 10^{10}$ gene copies/g, respectively, which was lower than that in AR treated with $\mathrm{Cl}_{2}$ alone (Fig. 7a). This indicated that UV could control the bacterial regrowth in ARs. At stage II, the chlorine residual increased to $0.08 \mathrm{mg} / \mathrm{L}$ in both ARs. The gene copy number of $16 \mathrm{~S}$ rRNA was $1.37 \times 10^{9}$ gene copies/L in effluents of AR treated with $\mathrm{UV} / \mathrm{Cl}_{2}$, and it was $4.71 \times 10^{9}$ gene copies/L in effluents of AR treated with $\mathrm{Cl}_{2}$ alone. Therefore, the increase of chlorine residual effectively controlled the bacterial regrowth in effluents of both ARs at stage II, and UV also decreased the total bacterial number in effluents of AR obviously. However, the gene copy number of $16 \mathrm{~S}$ rRNA in biofilms of both ARs increased to about $5.70 \times 10^{10}$ gene copies/g. This was because the formation of corrosion products protected the biofilms from chlorine disinfection.

The dominant bacterial community composition in biofilms was compared at the genus level for different samples (Fig. 7b). At stage I, the main bacterial genera were Novosphingobium, Pseudorhodoferax, Sediminibacterium and Methyloversatilis in AR treated with $\mathrm{Cl}_{2}$ alone, and their relative abundance was $16.4 \%, 15.6 \%, 13.2 \%$ and $10.5 \%$, respectively. At this stage, the main bacterial genus was Norcardioeds, and its relative abundance was 9.65\% in AR treated with $\mathrm{UV} / \mathrm{Cl}_{2}$. At stage II, the bacterial genera Hydrogenophaga (13.3\%), Rhodobacter (9.68\%) and Sediminibacterium (7.52\%) dominated in the biofilms of AR treated with $\mathrm{Cl}_{2}$ alone, and Dechloromonas (25.9\%) dominated in the biofilms of AR treated with UV/ $\mathrm{Cl}_{2}$. Therefore, $\mathrm{UV} / \mathrm{Cl}_{2}$ disinfection impacted the bacterial community composition in biofims of DWDSs comparing with $\mathrm{Cl}_{2}$ disinfection alone. At stage I, total bacterial number in biofilms was less in both ARs because the relative stable corrosion scales was not formed, therefore, the chemical corrosion caused by chlorine was the main corrosion process, and the bacterial role on the corrosion was weak. At stage II, the relative stable corrosion scales was formed. Bacteria in biofilms played great roles in the corrosion process. Hydrogenophaga and Sediminibacterium could promote the corrosion rate by the iron oxidation in the AR treated $\mathrm{Cl}_{2}$ alone (Wang et al., 2014), but $\mathrm{UV} / \mathrm{Cl}_{2}$ disinfection induced the bacterial genus Dechloromonas dominant in biofilms. Dechloromonas could initiate the microbial redox cycling of iron (Coby et al., 2011), and our previous studies had indicated that microbial redox cycling of iron induced by this bacteria genus in corrosion process could inhibit the corrosion effectively (Wang et al., 2014, 2015). Therefore, $\mathrm{UV} / \mathrm{Cl}_{2}$ disinfection impacted the corrosion process and decreased the corrosion rate by adjusting the bacterial community composition in biofilms at stage II.

Moreover, many studies have indicated that Mycobacterium, Pseudomonas, Xanthobacter, Porphyrobacter, Hyphomicrobium, Methylobacterium and Afipia are the dehalogenation related bacteria because these bacteria could reduce the DBPs in some conditions (McDonald et al., 2002; McRae et al., 2004; Sfetsas et al., 2009; Zhang et al., 2009; Chuang and Tung, 2012; Jang et al., 2012). The total relative abundance of the dehalogenation related bacteria in biofilms of $\mathrm{AR}$ treated with $\mathrm{Cl}_{2}$ alone increased from $6.34 \%$ at stage I to $6.55 \%$ at stage II. Moreover, it decreased from $4.48 \%$ to $3.24 \%$ in AR treated with $\mathrm{UV} / \mathrm{Cl}_{2}$ (Fig. $7 \mathrm{c}$ ). However, the number of the total bacteria increased $1-2$ folds in the biofilms at stage II (Fig. 7a). Therefore, the real number of the dehalogenation related bacteria in biofilms of both ARs increased at stage II, and it was 1-fold higher in AR treated with $\mathrm{Cl}_{2}$ alone than that treated with $\mathrm{UV} / \mathrm{Cl}_{2}$. Some reports had indicated that DBPs would be 



Fig. 7. (a) The gene copy number of $16 \mathrm{~S}$ rRNA in biofilms and effluents, and the relative abundance of (b) different bacteria and (c) the dehalogenation related bacteria at genus level in biofilms of different ARs. The different bacteria with the relative abundance lower than $5 \%$ in (b) were assigned to others.

reduced by the bacteria in biofilms in simulated DWDSs (Baribeau et al., 2005; Jang et al., 2012). Therefore, the dehalogenation related bacteria in biofilms of both ARs may also affect the removal of DBPs.

At stage I, although the bacterial number was lower in AR treated with $\mathrm{UV} / \mathrm{Cl}_{2}$, the higher corrosion current density and corrosion rate induced the more removal of DOC and DBPs in this
AR by the roles of $\mathrm{Fe}^{0}$ and corrosion products. Therefore, at stage I, the corrosion is the main reason for the removal of DOC and DBPs. At stage II, the corrosion reached a relative stable stage in both ARs and more corrosion products formed on the surface of cast iron coupons. Meanwhile, the number of total bacteria and dehalogenation related bacteria increased in biofilms of both ARs at this stage, resulting in the more removal of DOC and DBPs in both ARs. However, Hydrogenophaga and Sediminibacterium could increase the corrosion rate by the iron oxidation, and Dechloromonas could inhibit corrosion by the microbial redox cycling of iron (Coby et al., 2011; Wang et al., 2014, 2015). Correspondingly, the corrosion current density and corrosion rate were higher in AR treated with $\mathrm{Cl}_{2}$ alone than that treated with $\mathrm{UV} / \mathrm{Cl}_{2}$. Under this condition, the number of total bacteria and dehalogenation related bacteria were also higher in $\mathrm{AR}$ treated with $\mathrm{Cl}_{2}$ alone. The more total bacteria growth could consume more NOM (Codony et al., 2002), which induced more removal of DOC. The more dehalogenation related bacteria induced the more removal of DBPs by the reduction of DBPs (Baribeau et al., 2005; Jang et al., 2012). Therefore, the removal of DOC and DBPs was mainly caused by the corrosion and the number of bacteria in biofilms at stage II. Moreover, the removal of DOC and DBPs were lower in AR treated with $\mathrm{UV} / \mathrm{Cl}_{2}$ than that treated with $\mathrm{Cl}_{2}$ alone at this stage.

\section{Conclusions}

The results showed that UV dose of $40 \mathrm{~mJ} / \mathrm{cm}^{2}$ had little effect on the changes of NOM structure. Chlorine reacted easily with the phenolic $\mathrm{OH}$ group and $\mathrm{C}-\mathrm{H}$ of aromatic ring to form DBPs. The removal of DOC and DBPs was related to the corrosion process and bacterial regrowth in both ARs. At stage I, corrosion was the main reason for the removal of DOC and DBPs. The higher corrosion rate induced the higher removal of DOC and DBPs in AR treated with $\mathrm{UV} / \mathrm{Cl}_{2}$. At stage II, the more corrosion products and total bacteria including the dehalogenation related bacteria were formed, therefore, higher removal of DOC and DBPs was found in both ARs at this stage. However, comparing with the AR treated with $\mathrm{Cl}_{2}$ alone, $\mathrm{UV} / \mathrm{Cl}_{2}$ disinfection could control the bacterial regrowth in $\mathrm{AR}$, and the number of total bacteria and the dehalogenation related bacteria was less in this AR. Moreover, $\mathrm{UV} / \mathrm{Cl}_{2}$ disinfection decreased the corrosion rate by adjusting the bacterial community composition. Therefore, the removal of DOC and DBPs were lower in AR treated with $\mathrm{UV} / \mathrm{Cl}_{2}$ than that in AR treated with $\mathrm{Cl}_{2}$ alone. These results are very helpful for the control of NOM and DBPs in DWDSs with different disinfection.

\section{Acknowledgments}

This work was funded by the National Natural Science Foundation of China (Nos. 51308529, 51290281).

\section{References}

Abdullah, Md.P., Yee, L.F., Ata, S., Abdullah, A., Ishak, B., Abidin, K.N.Z., 2009. The study of interrelationship between raw water quality parameters, chlorine demand and the formation of disinfection by-products. Phys. Chem. Earth 34, 806-811.

Baribeau, H., Krasner, S.W., Chinn, R., Singer, P.C., 2005. Impact of biomass on the stability of HAAs and THMs in a simulated distribution system. J. AWWA 97, 69-81.

Carvalho, S.I.M., Otero, M., Duarte, A.C., Santos, E.B.H., 2008. Spectroscopic changes on fulvic acids from a kraft pulp mill effluent caused by sun irradiation. Chemosphere 73, 1845-1852.

Choi, Y., Choi, Y.J., 2010. The effects of UV disinfection on drinking water quality in distribution systems. Water Res. 44, 115-122.

Chun, C.L., Hozalski, R.M., Arnold, W.A., 2005. Degradation of drinking water disinfection byproducts by synthetic goethite and magnetite. Environ. Sci. Technol. 39, 8525-8532. 
Chun, C.L., Hozalski, R.M., Arnold, W.A., 2007. Degradation of disinfection byproducts by carbonate green rust. Environ. Sci. Technol. 41, 1615-1621.

Chuang, Y.H., Tung, H.H., 2012. Isolation of HAA degrading bacteria from drinking water using complex media. Sustain. Environ. Res. 22, 287-294.

Coby, A.J., Picardal, F., Shelobolina, E., Xu, H.F., Roden, E.E., 2011. Repeated anaerobic microbial redox cycling of iron. Appl. Environ. Microbiol. 77, 6036-6042.

Codony, F., Morato, J., Ribas, F., Mas, J., 2002. Effect of chlorine, biodegradable dissolved organic carbon and suspended bacteria on biofilm development in drinking water systems. J. Basic Microbiol. 42, 311-319.

Dotson, A.D., Keen, V.O.S., Metz, D., Linden, K.G., 2010. UV $/ \mathrm{H}_{2} \mathrm{O}_{2}$ treatment of drinking water increases post-chlorination DBP formation. Water Res. 44 3703-3713.

EPA of China, 2002. Analysis Method for Water and Waste Water, fourth ed. Press of Chinese Environmental Science, Beijing.

Fernandez-Calvino, D., Soler-Rovira, P., Polo, A., Arias-Estévez, M., Plaza, C., 2010 Influence of humified organic matter on copper behavior in acid polluted soils. Environ. Pollut. 158, 3634-3641.

Guilherme, S., Rodriguez, M.J., 2015. Short-term spatial and temporal variability of disinfection by-product occurrence in small drinking water systems. Sci. Tota Environ. 518-519, 280-289.

Her, N., Amy, G., Foss, D., Cho, J.W., 2002. Variations of molecular weight estimation by HP-size exclusion chromatography with UVA versus online DOC detection. Environ. Sci. Technol. 36, 3393-3399.

Hozalski, R.M., Zhang, L., Arnold, W.A., 2001. Reduction of haloacetic acids by Fe ${ }^{0}$ : implications for treatment and fate. Environ. Sci. Technol. 35, 2258-2263.

Hwang, C., Ling, F.Q., Andersen, G.L., LeChevallier, M.W., Liu, W.T., 2012. Microbia community dynamics of an urban drinking water distribution system subjected to phases of chloramination and chlorination treatments. Appl. Environ. Microb. 78, 7856-7865.

Jang, H.J., Choi, Y.., Ro, H.M., Ka, J.O., 2012. Effects of phosphate addition on biofilm bacterial communities and water quality in annular reactors equipped with stainless steel and ductile cast iron pipes. J. Microbiol. 50, 17-28.

Kanokkantapong, V., Marhaba, T.F., Panyapinyophol, B., Pavasant, P., 2006. FTIR evaluation of functional groups involved in the formation of haloacetic acids during the chlorination of raw water. J. Hazard. Mater 136, 188-196.

Lee, J.Y., Hozalski, R.M., Arnold, W.A., 2007. Effects of dissolved oxygen and iron aging on the reduction of trichloronitromethane, trichloracetonitrile, and trichloropropanone. Chemosphere 66, 2127-2135.

Lee, J.Y., Pearson, C.R., Hozalski, R.M., Arnold, W.A., 2008. Degradation of trichloronitromethane by iron water main corrosion products. Water Res. 42, 2043-2050.

Li, X.X., Wang, H.B., Zhang, Y., Hu, C., Yang, M., 2014. Characterization of the bacterial communities and iron corrosion scales in drinking groundwater distribution systems with chlorine/chloramines. Int. Biodeterior. Biodegr. 96, 71-79.

Liu, W., Andrews, S.A., Bolton, J.R., Linden, K.G., Sharpless, C.M., Stefan, M., 2002 Comparison of disinfection byproduct (DBP) formation from different UV technologies at bench scale. Water Sci. Technol. 2, 515-521.

Liu, W., Cheung, L.M., Yang X., Shang, C., 2006. THM, HAA and $\mathrm{CNCl}$ formation from UV irradiation and chlor(am)ination of selected organic waters. Water Res. 40 2033-2043.

Liu, W., Zhang, Z.L., Yang, X., Xu, Y.Y., Liang, Y.M., 2012. Effects of UV irradiation and UV/chlorine co-exposure on natural organic matter in water. Sci. Total Environ. 414, 576-584.

Lyon, B.A., Cory, R.M., Weinberg, H.S., 2014. Changes in dissolved organic matter fluorescence and disinfection byproduct formation from UV and subsequent chlorination/chloramination. J. Hazard. Mater 264, 411-419.

McDonald, I.R., Warner, K.L., McAnulla, C., Woodall, C.A., Oremland, R.S. Murrell, J.C., 2002. A review of bacterial methyl halide degradation: biochemistry, genetics and molecular ecology. Environ. Microbiol. 4, 193-203.

McRae, B.M., LaPara, T.M., Hozalski, R.M., 2004. Biodegradation of haloacetic acids by bacterial enrichment cultures. Chemosphere 55, 915-925.

Perez-Sanz, A., Lucena, J.J., Graham, M.C., 2006. Characterization of Fe-humic complexes in an Fe-enriched biosolid by-product of water treatment. Chemosphere 65, 2045-2053.

Rao, P., Mak, M.S.H., Liu, T.Z., Lai, K.C.K., Lo, I.M.C., 2009. Effects of humic acid on arsenic (V) removal by zero-valent iron from groundwater with special references to corrosion products analysis. Chemosphere 75, 156-162.

Samios, S., Lekkas, T., Nikolaou, A., Golfinopoulos, S., 2007. Structural investigations of aquatic humic substances from different watersheds. Desalination 210, 125-137.

Sarin, P., Snoeyink, V.L., Bebee, J., Kriven, W.M., Clement, J.A., 2001. Physicochemical characteristics of corrosion scales in old iron pipes. Water Res. 35, 2961-2969.

Sfetsas, C.C. Milios, L., Skopelitou, K. Venieraki, A., Todou, R., Flemetakis, E. Katinakis, P., Labrou, N.E., 2009. Characterization of 1,2-dibromoetane-degrading haloalkane dehalogenase from Bradyrhizobium japonicum USDA 110. Enzyme Microb. Tech. 45, 397-404.

Shah, A.D., Dotson, A.D., Linden, K.G., Mitch, W.A., 2011. Impact of UV disinfection combined with chlorination/chloramination on the formation of halonitromethanes and haloacetonitriles in drinking water. Environ. Sci. Technol. 45, 3657-3664.

Shanks, C.M., Serodes, J.B., Rodriguez, M.J., 2013. Spatio-temporal variability of nonregulated disinfection by-products within a drinking water distribution network. Water Res. 47, 3231-3243.

Suzuki, M.T., Taylor, L.T., DeLong, E.F., 2000. Quantitative analysis of small-subunit rRNA genes in mixed microbial populations via 5'-nuclease assays. Appl. Environ. Microbio. 66, 4605-4614

Tsang, D.C.W., Graham, N.J.D., Lo, I.M.C., 2009. Humic acid aggregation in zerovalent iron systems and its effects on trichloroethylene removal. Chemosphere $75,1338-1343$

Usher, K.M., Kaksonen, A.H., Cole, I., Marney, D., 2014. Critical review: microbially influenced corrosion of buried carbon steel pipes. Int. Biodeterior. Biodegr. 93, 84-106.

Wang, H.B., Hu, C., Zhang, L.L., Li, X.X., Zhang, Y., Yang, M., 2014. Effects of microbial redox cycling of iron on cast iron pipe corrosion in drinking water distribution system. Water Res. 65, 362-370.

Wang, H.B., Hu, C., Han, L.C., Yang, M., 2015. Effects of microbial cycling of Fe(II)/ $\mathrm{Fe}(\mathrm{III})$ on cast iron corrosion in simulated drinking water distribution systems. Corros. Sci. 100, 599-606.

Xiao, J.N., Yue, O.Y., Gao, B.Y., Sun, Y.Y., Kong, J.J., Gao, Y., Li, O., Wang, Y., 2014. Performance of activated carbon/nanoscale zero-valent iron for removal of trihalomethanes (THMs) at infinitesimal concentration in drinking water. Chem. Eng. J. 253, 63-72.

Zhang, P., Lapara, T.M., Gosla, E.H., Xie, Y., Parsons, S.A., Hozalski, R.M., 2009. Biodegradation of haloacetic acids by bacterial isolates and enrichment cultures from drinking water systems. Environ. Sci. Technol. 43, 3169-3175.

Zarasvand, K.A., Rai, V.R., 2014. Microorganisms: induction and inhibition of corrosion in metals. Int. Biodeterior. Biodegr. 87, 66-74. 